J. Product. \& Dev., 23(1): 23-37 (2018)

\title{
TRIALS FOR IMPROVING THE PRODUCTIVITY AND REDUCING SHOT BERRIES IN SUPERIOR GRAPEVINES BY USING SILICON AND GLUTATHIONE
}

\author{
Faissal F. Ahmed*; Ahmed.H.M. Abdelaal**; Salah-Eldeen .M.A. El- \\ Masry** and Mohamed A. Metwally **. \\ *Hort. Dept., Fac. of Agriculture, Minia Univ. , Minia, Egypt. \\ **Hort. Dept., Fac. of Agriculture, El-Azhar Univ., Assuit branch, Egypt.
}

\begin{abstract}
During 2014 \& 2015 seasons, Superior grapevines were treated three times with potassium silicate and/or glutathione each at 0.05 to $0.2 \%$. The merit of this study was examining the effect of single and combined applications of potassium silicate and glutathione at different concentration on growth and fruiting of Superior grapevines.

Treating the vines with potassium silicate and/or glutathione three times at 0.05 to $0.2 \%$ was very effective in enhancing growth aspects, leaf pigments, nutrients, yield and both physical and chemical characteristics of the berries over the control treatment. The promotion was associated with increasing the concentrations. Negligible promotion on these parameters was observed among the higher two concentrations namely 0.1 and $0.2 \%$. Using glutathione was greatly superior than using potassium silicate in all parameters.

Conclusively, according to the obtained data, it is suggested to use a mixture of potassium silicate and glutathione each at $0.1 \%$ three times at growth start, just after berry setting and at one month later gave the best results with regard to yield and berries quality of Superior grapevines.
\end{abstract}

Keywords: Superior, glutathione, silicon, yield, fruit quality

\section{INTRODUCTION}

The decline in the yield and the inferior on grapes quality due to the occurrence of small berries and the presence of higher shot berries in clusters of such grape cv represent the most important serious problems which face the production and produce unfavourable clusters from the consumer point of view. Using antioxidants such as silicon and glutathione increased the tolerance of the trees to biotic and abiotic stress that succeeded in solving these problems. 
Recently, silicon is used for improved yield and quality of Superior grapevines grown under different stresses. The favourable effects of silicon on fruiting seem to originate from its positive action on enhancing the tolerance of plants to biotic and abiotic stresses and drought tolerance. This is explained in the light of its impact on enhancing water retention and photosynthesis via formation of silicon cuticle double layers formed on leaf epidermal tissue. (Matoh et al., 1991; Ma, 2004; Hattori et al., 2005 and Tahir et al., 2006).

Glutathione is the most important non-protein thiol present in plants. It is essential in sulfur metabolism and defense against most stresses. It is important pool of reduced sulfur and it regulates sulfur uptake at root level. Reduced glutathione, the major water soluble antioxidant in photosynthetic and nonphotosynthetic tissues, reacting directly or indirectly with reactive oxygen species, contribute to maintain the integrity of cell structure and the proper functions of various metabolic pathways. In addition to its effects on expression of defense genes glutathione may also be involved in redox control of cell division and enhanced growth of plants (Mulleineaux and Rausch, 2005).

The findings regarding the promoting effect of silicon on growth and fruiting of Superior grapevines and other fruit crops are in harmony with those obtained by Abd El- Hameed, (2012), Gad El- Kareem (2012), Ahmed et al., (2013), Abdelaal and Oraby- Mona (2013); Al Wasfy (2014), El- Khawaga (2014), El- Khawaga and Mansour (2104); Ibrahim and Al- Wasfy (2014), Gad El- Kareem et al., (2014), Uwakiem, (2015), Wassel et al., (2015), Akl et al., (2016), Nagy-Dina (2016), Youssef (2017) and Farahat (2017).

Previous studies showed that glutathione had an announced promotion on growth, yield and fruit quality in different fruit crops Abdelaal et al., (2012), Gad El-Kareem (2012), Ahmed et al., (2012), Ahmed et al., (2013) and ElKhawaga and Mansour (2014).

Therefore, the objective of this study was examining the effect of single and combined applications of silicon and glutathione on vegetative growth aspects, vine nutritional status, yield and berries quality of Superior grapevines grown under clay soil.

\section{MATERIALS AND METHODS}

This study was carried out during 2014 and 2015 seasons on thirty uniform in vigour of 14 years- old Superior grapevines. The selected vines are grown in a private vineyard situated at Kom Wally village, Matay district, Minia Governorate where the texture of the soil is clay (Table 1). Soil analysis was done according to the procedures that outlined by Black (1965). 
Table (1): Analysis of the tested soil

\begin{tabular}{|l|c|}
\hline Constituent & Values \\
\hline Sand \% & $\mathbf{5 . 9}$ \\
Silt $\%$ & $\mathbf{1 5 . 0}$ \\
Clay $\%$ & $\mathbf{7 9 . 1}$ \\
Texture & clay \\
O.M. \% & $\mathbf{2 . 4 9}$ \\
pH $(1: 2.5$ extract) & $\mathbf{7 . 9 5}$ \\
EC $\left(1: 2.5\right.$ extract) (mmhos $\left./ \mathrm{cm} / 25^{\circ} \mathrm{C}\right)$ & $\mathbf{0 . 8 9}$ \\
CaCO $\%$ & $\mathbf{2 . 1 1}$ \\
Total $\%$ & $\mathbf{0 . 0 9}$ \\
Available P (Olsen method , ppm) & $\mathbf{4 . 9 0}$ \\
Available K (ammonium acetate, $\mathrm{ppm})$ & $\mathbf{4 . 9 0}$ \\
\hline
\end{tabular}

The selected vines are planted at $1.5 \times 3$ meters apart. The chosen vines were trained by cane pruning system leaving 72 eyes/ vine (six fruiting canes $\mathrm{x}$ 10 eyes plus six renewal spurs / two eyes) using Gable supporting method. Surface irrigation system was followed by using Nile water.

Except those dealing with the present treatments (application of silicon and glutathione), the selected vines (30 vines) received the usual horticultural practices that are commonly applied in the vineyard including the application of $250 \mathrm{~kg}$ ammonium nitrate, $20 \mathrm{~m} 3$ F.Y.M. $150 \mathrm{~kg}$ calcium superphosphate (15.5\% P2O5) and $200 \mathrm{~kg}$ potassium, sulphate (48\% K2O) per one fedddan annually. Farmyard manure was added once at the middle of Jan, while mineral $\mathrm{N}$ was divided into three unequal batches added as $40 \%$ at growth start $30 \%$ just after berry setting and $30 \%$ at two weeks later. Phosphate fertilizer was added once at the middle. of Jan. Potassium fertilizer was applied twice at growth start (middle of Feb.) and again just after berry setting (middle of April) during both seasons. Another horticultural practices such as two hoeing's, irrigation, pinching and pest management were carried out as usual.

This experiment consisted from ten treatments from single and combined applications of potassium silicate and glutathione in addition to the control treatment could be arranged as follows:

1. Control

2. Spraying potassium silicate at $0.05 \%(0.5 \mathrm{~g} / \mathrm{l})$

3. Spraying potassium silicate at $0.1 \%(1.0 \mathrm{~g} / \mathrm{l})$

4. Spraying potassium silicate at $0.2 \%(2.0 \mathrm{~g} / \mathrm{l})$

5. Spraying glutathione at $0.05 \%(0.5 \mathrm{~g} / \mathrm{l})$

6. Spraying glutathione at $0.1 \%(1.0 \mathrm{~g} / \mathrm{l})$ 
7. Spraying glutathione at $0.2 \%(2.0 \mathrm{~g} / \mathrm{l})$

8. Spraying potassium silicate+ glutathione each at $0.05 \%(0.5 \mathrm{~g} / \mathrm{l})$

9. Spraying potassium silicate+ glutathione each at $0.1 \%(1.0 \mathrm{~g} / \mathrm{l})$

10. Spraying potassium silicate+ glutathione each at $0.2 \%(2.0 \mathrm{~g} / \mathrm{l})$

Each treatment was replicated three times, one vine per each. Both potassium silicate and glutathione were sprayed three times starting at growth start ( $1^{\text {st }}$ week of Mar.), just after berry setting ( $2^{\text {nd }}$ week of Apr.) and at one month later $\left(2^{\text {nd }}\right.$ week of May).

Randomized complete block design (RCBD) was adopted for carrying out statistical analysis of this study (Snedecor and Cochran, 1990)

During both seasons the following measurements were recorded:

1- Vegetative growth characteristics namely main shoot length $(\mathrm{cm})$, number of leaves/shoot, leaf area (cm2) (Ahmed and Morsy, 1999), wood ripening coefficient (Bourad, 1966), pruning wood weight (kg.) and cane thickness $(\mathrm{cm})$.

2- Leaf chemical components namely chlorophylls a \& b, total chlorophylls, total carotenoids (mg/ $1 \mathrm{~g} \mathrm{F.W.),} \mathrm{N,} \mathrm{P,} \mathrm{K,} \mathrm{Mg} \mathrm{(as} \mathrm{\% ),} \mathrm{Zn,} \mathrm{Cu,} \mathrm{Mn} \mathrm{and} \mathrm{Fe}$ (as ppm) in the leaves (Cottenie et al, 1982 and Summer, 1985).

3- Percentage of berry setting, yield/vine (kg.), number of clusters per vine as well as weight (g.), length and shoulder of clusters (cm)

4- Percentage of shot berries

5- Physical and chemical characteristics of the berries namely berry weight (g.), longitudinal and equatorial (cm.), T.S.S.\%, total sugars and total acidity\% (as g tartaric acid/100 $\mathrm{ml}$ juice) (A.O.A.C., 2000).

Statistical analysis was done using new L.S.D. at 5\% (Mead et al., 1993).

\section{RESULTS AND DISCUSSION}

\section{1-Vegetative growth characteristics:}

It is clear from the data in Table (2) that growth aspects namely main shoot length, number of leaves/ shoot, leaf area, wood ripening coefficient, pruning wood weight and cane thickness were significantly stimulated in response to single and combined applications of potassium silicate and glutathione each at 0.05 to $0.2 \%$ relative to the control treatment. The stimulation was associated with increasing the concentrations. Using glutathione was significantly superior than using potassium silicate in this respect. Also, combined applications were significantly favourable than using 
each material alone in this respect. Using both materials together at $0.2 \%$ gave the highest values. These results were true during both seasons.

\section{2- Chemical constituents of leaves:}

It is revealed from the data in Tables ( $3 \& 4$ ) that Subjecting the vines to single and combined applications of potassium silicate and/or glutathione each at 0.05 to $0.2 \%$ was significantly accompanied with enhancing chlorophylls a \& b, total chlorophylls, total carotenoids, $\mathrm{N}, \mathrm{P}, \mathrm{K}, \mathrm{Mg}, \mathrm{Zn}, \mathrm{Fe}$ and $\mathrm{Mn}$ in the leaves rather than non-application. Leaf content of $\mathrm{Cu}$ was significantly unaffected by the present treatment. Spraying both materials together at $0.2 \%$ gave the highest values. These results were true in both seasons.

\section{3-Percentage of berry setting, yield and cluster aspects}

It is obvious from the data in Table ( 5 ) that berry setting \%, yield $(\mathrm{Kg})$ and cluster aspects of Superior grapevines were significantly improved in response to single and combined applications of potassium silicate and/or glutathione each at 0.05 to $0.2 \%$ compared to the control treatment. The promotion was in proportional to the increase in the concentrations. Increasing concentrations from 0.1 to $0.2 \%$ had meaningless promotion. Therefore, from economical point of view, it is advised to use both materials at $0.1 \%$. Also, using glutathione was superior than using potassium silicate. Combined applications were preferable than using each one alone in improving berry setting, yield and cluster aspects. Similar results were true in both seasons.

\section{4- Percentage of shot berries:}

It is clear from the data in Table (6) that single and combined applications of silicon and glutathione significantly reduced the percentage of shot berries relative to the control treatment. The reduction was clearly associated with increasing the concentrations of silicon and glutathione. It is appeared that the reduction on shot berries occurred by glutathione was higher than those occurred by potassium silicate. The lowest values were recorded on the clusters harvested from vines treated with both materials together at $0.2 \%$. These results were nearly the same during both seasons.

\section{5- Quality of the berries:}

One can state form the data in Table (6) that treating the vines with potassium silicate and/or glutathione each at 0.05 to $0.2 \%$ was significantly very effective in enhancing quality of the berries in terms of increasing berry weight and dimensions (longitudinal and equatorial) T.S.S. \%, and reducing 
sugars $\%$ and decreasing total acidity $\%$ relative to the control treatment. The promotion was depended on increasing concentrations of each material. Application of glutathione surpassed the application of potassium silicate in this connection. Combined applications were significantly preferable than using each alone in enhancing fruit quality. These results were true in both seasons.

\section{DISCUSSION}

Previous studies showed that the favourable effects of silicon on growth, nutritional status of vines and fruiting seem to originate from its positive action on enhancing the tolerance of plants to biotic and abiotic stresses and drought tolerance. This is attributed to its essential role in maintaining plant water balance, photosynthetic activity and erecting the structure of xylem vessels. Previous studies explained these benefits to the formation of silica cuticle double layers formed on leaf epidermal tissue. Silicon also is responsible for water transport and root development as well as increasing the tolerance of plants to controlling powdery mildew. The mechanical strength provided by silicon to the plant tissues increases their resistance to diseases and insects and is responsible for reducing the adverse effects of heavy metal toxicity (Matoh et al., 1991; Lux et al., 2003; Rodriguez et al., 2003; Ma, 2004; Hattori et al., 2005 and Tahir et al., 2006).

The findings regarding the promoting effect of silicon on growth and fruiting of Superior grapevines and other fruit crops are in harmony with those obtained by Al Wasfy (2014); El- Khawaga (2014), El- Khawaga and Mansour (2104); Ibrahim and Al- Wasfy (2014), Gad El- Kareem et al., (2014), Uwakiem, (2015), (Wassel et al., (2015), Akl et al., (2016), NagyDina (2016), and Farahat (2017).

Glutathione is the most important non-protein thiol present in plants. It is essential in sulfur metabolism and defense against most stresses. It is important pool of reduced sulfur and it regulates sulfur uptake at root level. Reduced glutathione, the major water soluble antioxidant in photosynthetic and non- photosynthetic tissues, reacting directly or indirectly with reactive oxygen species, contribute to maintain the integrity of cell structure and the proper functions of various metabolic pathways. In addition to its effects on expression of defense genes glutathione may also be involved in redox control of cell division and enhanced growth of plants (Mulleineaux and Rausch, 2005). 
These results are in harmony with those obtained by Abdelaal et al., (2012), Gad El-Kareem (2012), Ahmed et al., (2012), Ahmed et al., (2013) and El- Khawaga and Mansour (2014).

Conclusively, according to the obtained data, it is suggested to use a mixture of potassium silicate and glutathione each at $0.1 \%$ three times at growth start, just after berry setting and at one month later for promoting vegetative growth aspects, yield and fruit quality of Superior grapevines.

\section{REFERENCES}

Abdelaal, A.M.K. and Oraby-Mona, M.M (2013): Using silicon for increasing the tolerance of mango cv Ewaise transplants to drought. World Rural Observations, 5(2):36-40.

Abdelaal, A.M.K.; Masoud, A.A.B. and Mohamed, A.Y. (2012): Response of Taimour mango trees to application of the antioxidant glutathione. Menufiya J., Agric. Res., Vol. (3): 303-310.

Abd El-Hameed, H.M. (2012): Using silicon, boron and folic acid to promote yield quantitatively and qualitatively of Early Superior grapevines. Minia J, of Agric. Res.\& Develop. , Vol. (32) No. 5: 869-886.

Ahmed, F. F. and Morsy, M. H. (1999): A new method for measuring leaf area in different fruit crops. Minia of Agric. Res. \& Develop., Vol. (19) pp. 97-105.

Ahmed, F.F.; Al-Wasfy, M.M. and Madian, A.M. (2012): Fruiting of Zaghloul date palms in response to foliar application of the antioxidant glutathione. Minia J. of Agric. Res. \& Develop., 32(4): 1123-1140.

Ahmed, F.F.; Gad El- Kareem, M. R. and Oraby- Mona MM. (2013): Response of Zaghloul date palms to spraying boron, silicon and glutathione. Stem Cell , 4(2): 29-34.

Akl A.M.M; Mohamed, M.A.; El- Sayed, M.A. and Moustafa, M.M.H. (2016): Behaviour of Superior grapevines to spraying silicon. J. Biol. Chem. Environ. Sc., 11(3): 403- 412.

Al-Wasfy, M.M. (2014): The synergistic effects of using silicon with some vitamins on growth and fruiting of Flame seedless grapevines. Stem Cell, 5(1): $8-13$.

A.O.A.C. (2000): Association of Official Agricultural Chemists. Official Methods of Analysis . 12th Ed., Benjamin Franklin Station, Washington D.C., U.S.A.pp.490-510.

Black, C.A. (1965): Methods of Soil Analysis. Amer. Soc. of Agron., Madison, Wisconsin, U.S.A. pp 1 - 20. 
Bouard, J. (1966): Recharches, physiologiques sur la vigen at en particulier sur laoudment des serments. Thesis Sci. Nat. Bardeux France, p.34.

Cottenie, A.; Verloo, M.; Velghe, M. and Camerlynck, R. (1982): Chemical Analysis of Plant and Soil. Ghent, Belgium, Laboratory of Analytical and Agro- chemistry. State Univ. pp. 200-210.

El-Khawaga, A.S. (2014): Impact of vitamins B and C, glutamic acid and silicon on fruiting of Superior grapevines. World Rural Observations, 6(4): 57-62.

El-Khawaga, A.S. and Mansour, A.G.M. (2014): Promoting productivity of Washington Navel orange trees by using some crop seed sprout extracts, silicon and glutathione. Middle East Journal of Applied Sciences, 4(3): 779-785.

Farahat, I.A.M. (2017): Studies on pruning and fertilization of Early Sweet grapevines growing under Minia Region condition. Ph.D. Thesis Fac. of Agric. Minia Univ., Egypt.

Gad El- Kareem, M.R. (2012): Improving productively of Taimour mango trees by using glutathione, silicon and vitamin B. Minia J. of Agric. Res.\& Develop., 32(7): 1105-1121.

Gad El- Kareem, M.R.; Abdelaal, A.M.K. and Mohamed A.Y. (2014): The synergistic effect of using silicon and selenium on fruiting of Zaghloul date palm (Phoenic dectylifera L.) World Academy of Engineering and Technology. Inter. J. of Agric. Biosystems Sci. and Engineering, 8(3):959-964.

Hattori, T; Inanaga, S.; araki, H.; An, P.; Martia, S.; Luxova, M. and Lux, A. (2005): Application of silicon enhanced drought tolerance in Sorgham bicolor. Physiologia Plantarum, 123:459-466.

Ibrahiem, H.I.M. and Al- Wasfy, M.M. (2014): The promotive impact of using silicon and selenium with potassium and boron on fruiting of Valencia orange trees grown under Minia region conditions. World Rural Observations , 6 (2):28-36.

Lux, A.; Luxova, M.; Abe, J. Tanmoto, E. and Inanaga, S. (2003): The dynamic of silicon deposition in the sorghum root endodermis. New Physiol., 158:437-441.

Ma, J.F. (2004): Role of silicon in enhancing the resistance of plants of biotic and abiotic stresses. Soil Scr. Plant Nutr. 50:11-18.

Matoh, T.; Murata, S. and Takahashi, E. (1991): Effect of silicate application on photosynthesis of rice plants. Japan. J. Soil Sci. Plant Nutr., 62:248-251. 
Mead, R.; Currnow, R. N. and Harted, A. M. (1993): Statistical Methods in Agricultural and Experimental Biology. $2^{\text {nd }}$ Ed. Chapman and Hall, London pp. 10- 44.

Mulleineaux, P.M. and Rausch, T. (2005): Glutathione, photosynthesis and the redox regulation of stress responsive gene expression photosynthesis. Research, 47: 459-474.

Nagy-Dina, A.M. (2016): Response of Flame seedless grapevines to spraying silicon. M. Sc. Thesis Fac. of Agric. Minia Univ. Egypt.

Rodriguez, F.A.; Vale, F.X.R.; Karndorfar, G.H.; Prabhu, A.S.; Datnoff, L.E.; Oliveira, A.M.A. and Zambalim, L. (2003): Influence of silicon on sheath blight of rice in Brazil Crop Prot. 22:23-29.

Snedecor, G.W. and Cochran, W.G. (1990): Statistical Methods, $7^{\text {th }}$ Ed. The Iowa State Univ. Press Ames. Pp. 80- 100.

Summer, M.E. (1985): Diagnosis and Recommendation. Integrated system (DRIS) as a guide to orchard fertilization. Hort. Abst., 55(8): 7502.

Tahir, M.A.; Rahmatullah, A.; aziz, T.; Ashraf, M.; Kanwal, S. and Magsood, A. (2006): Beneficial effects of silicon in wheat (Triticum aestiviun E.) under salinity stress. Pak. J. Bot., 38(5):1715-1727.

Uwakiem, M. Kh., (2015). Effect of spraying silicon, selenium and humic acid on fruiting of Early Sweet grapevines. The $2^{\text {nd }}$ Inter. Conf. on Hort. Crops. 15-18 March., Egypt. J. Hort., 42(1): pp:333-343.

Wassel, A.M.M.; Abdelaziz, F.H.; Aly-Mervat, A. and Mohamed-Attiat, A.M. (2015): Trials for Alleviating the Adverse Effects of Salinity on Some Grapevine cvs. World Rural Observations, 7(4): 14-21.

Youssef, M.S.M. (2017): Effect of spraying silicon on fruiting of Sakkoti date palms. M.Sc. Thesis Fac. of Agric. Minia Univ. Egypt. 


\section{محاولات لتحسين الاتتاجية وتقليل الحبات الصغيرة فى كرمات العنب السوبيريور باستخدام السيليكون والجلوتاثيون التئين}

*فيصل فاضل احمد- **|حمد حسن عبدالعال- **صلاح الدين محمد على المصرى-

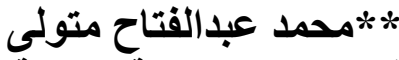

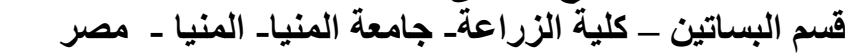
قسم البساتين- كلية الزراعةـ جامعة الأزهر - فرع أسيوط ـ مصر

خلال موسمى 2014 ، 2015 نم معاملة كرمات العنب السوبيريور ثلاثية

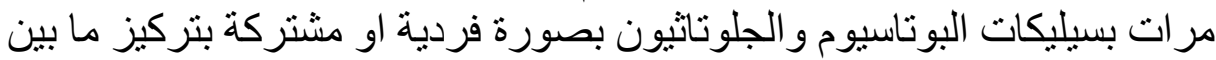

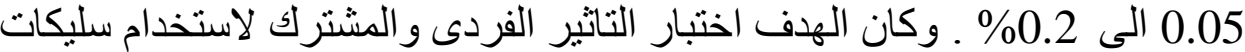

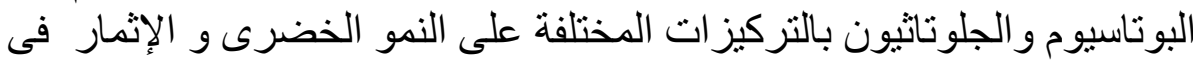

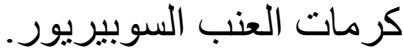

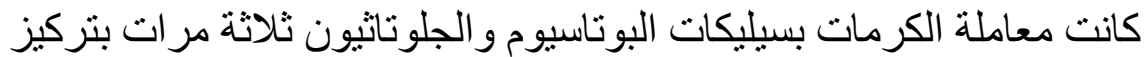

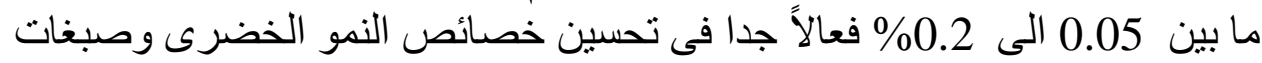

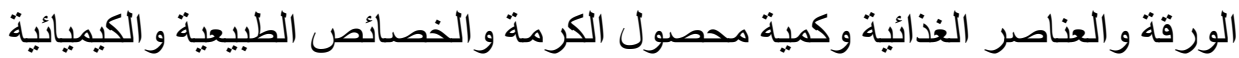

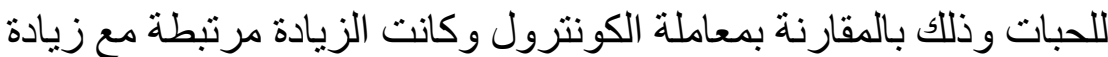

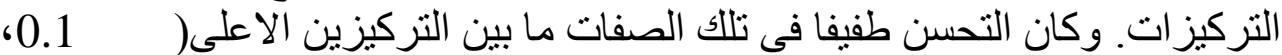

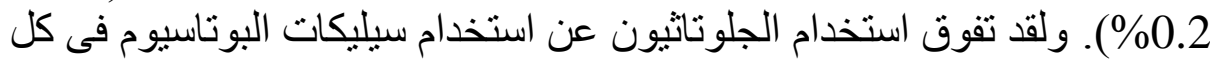
الصفات

التوصية: أمكن الحصول على أفضل النتائج بخصوص كمية محصول الكرمة

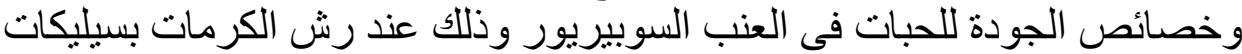

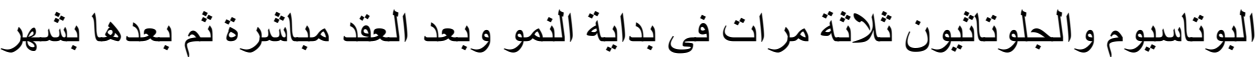

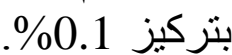
الكلمات الدالة: العنب السوبيريور - السيليكون- الجلوناثيون ـ كمية المحصول -

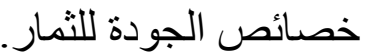


FAISSAL et al. 